\title{
Conflicts of Economic and Cultural Origin Between Farmers and Wild Animal Species in the Carpathian Basin - an Ethnozoological Approach
}

\author{
Dániel Babai - Viktor Ulicsni - Ákos Avar \\ Institute of Ethnology, RCH, Hungarian Academy of Sciences - \\ University of Szeged, Department of Ecology, Faculty of Science and Informatics - \\ Eötvös Loránd University, Faculty of Humanities, Mongolian and Central Asian Studies
}

\begin{abstract}
The multi-faceted relationship of society and wildlife is partly shaped by local perception determined by cultural or economic factors and resulting in positive or negative attitudes. The approach taken may influence the survival and the range of species and speciesgroups, in particular species associated with extremely negative emotions.

Connections between local communities and wild vertebrate species were studied in four regions within the Carpathian Basin (Gömör/Gemer - Slovakia, Szilágyság/Sălaj - Romania, Gyimes/Ghimeș - Romania and Drávaszög/Baranja - Croatia). During the work, spontaneous manifestations obtained in semi-structured interviews aiming at the exploration of the locally known fauna were taken into account.

Reviewing the five generally known families of vertebrates it can be stated, that - similarly to the global trends - the perception of amphibian and reptile species is extremely negative in the Carpathian Basin just as well. Most positive attitudes are related to bird species but due to presumed or true economic reasons some birds also include less favoured species. As to mammals, large predators are seen as harmful pests for husbandry and fearful for humans. The antipathy felt for bat species is an interesting phenomenon, mostly explained by their special physical constitution and mysterious lifestyle.

The perception of local communities originating from cultural or economic factors and resulting in varying signs may have an impact on the size of the populations of certain species or species-groups. Ethnozoological research provides significant help to deeper knowledge about background of connections between local communities and species of wildlife, motivations behind the activities of society has become of paramount importance for development of conservation strategies.
\end{abstract}

Keywords: perception, human-wildlife conflicts, ethnozoology, Carpathian Basin 


\section{INTRODUCTION}

Snakes, frogs and large predators - they were never welcomed by human communities, while certain bird species enjoy invariably high degree of love and respect. Relations between human culture and wildlife are shaped by deep-rooted, even thousands of years old cultural and/or economic habits, prejudices with positive or negative signs, social-demographic factors (sex and education), in addition to the complex set of interconnections provided by ecosystem services (PINHEIRo et al. 2016).

Land use practices of and reliance on ecosystem services by human communities living in regular and close intimacy with the natural environment requires a deep-rooted and thorough knowledge of the natural environment and wildlife (traditional ecological knowledge) (Berkes 2012; Menzies - ButLer 2006). Modernising, urbanised communities get into closer contact with the natural environment a lot less frequently (such as outdoor sports) and only through recreational and cultural ecosystem services, therefore their ecological perception and knowledge is often superficial and not built on hands-on experiences (PILGRIM et al. 2007). The difference between the knowledge of the two groups is significant, yet, whether more or less frequently, both of them have encounters with the representatives of the living world, and pay special attention to certain species, be it in the positive or negative sense just as well. Such a distinguished attention and sometimes extreme attitude is primarily directed to the representatives of the animal world, relations with plants are more neutral in nature.

Bad reputation may even seal the destiny of some species or groups of species, in spite of the fact that a community in direct dependence on the natural resources recognises the role and function of the group of animal species in the ecosystem (REGO et al. 2015) or in agriculture (pest control) (LAMARQue et al. 2009; PANDeY et al. 2016; Rego et al. 2015). Such prejudices afflict amphibians (such as frog and toad species), and reptiles (for instance, snakes) most frequently (CERÍACO 2012), including the Carpathian Basin (BABAI et al. 2016; GuB 1996; Kovícs 1987). Human communities feature extremely ambivalent, yet mainly negative relationships with amphibians and reptiles. Snakes emerge as worst of them. Perception and attitude towards snakes may be both positive and negative in human communities (PANDEY et al. 2016), but for most cases the relationship is extremely biased, some species belonging to snakes are the least liked animal species of the living world (Alves et al. 2014; FitA et al. 2010). There is a significant human-caused mortality of snakes e.g., in Nepal (PANDEY et al. 2016), India (Joshi - Joshi 2010), Brazil (Alves - Filho 2007; Moura et al. 2010), Kenya (WoJnowski 2009) and Australia (Whitaker - Shine 2000). The underlying cause is often the fear from venomous snakes (PANDEY et al. 2016). The same attitude prevails in the Carpathian Basin as well, where a number of legends and tales demonstrate that the perception of snakes has been ambivalent, but predominantly negative in Hungarian folk culture (BABAI et al. 2016; ERDÉsz 1972; 1984; RóHEIM 1925).

Even though the sharp distinction made between useful and harmful species based on the economic damages they cause seems to be an obsolete approach these days (cf. HERMAN 1901), yet, doubtlessly, farming communities still keep in evidence that there are species which cause harm or which are useful with respect of their specific activities (BABAI et al. 2016).

The relations between human and wildlife including the related traditional ecological knowledge is a significant area of ethnozoological research, which frequently gains 
specific importance in conservation efforts (ALVES 2012; HunTINGTON 2000; NADASDY 2007). The need of an approach to nature conservation from the perspective of human sciences (MASCIA et al. 2003) is shown particularly well by the complexity of the cultural and economic relations between human communities and wildlife (PANDEY et al. 2016; SALICK 2003). The efficacy of nature conservation efforts may be improved substantially by the exploration and a better understanding of the land use patterns and land transforming activities of human communities, including the underlying mental, cultural perception and motivations (Colding - FolKe 2001; MidDleton 2012). Research into traditional zoological knowledge may offer a great advantage to nature conservation in this respect (as well), drawing the attention of the experts to those groups of species the protection of which requires the consideration of various perceptions with cultural or economic origins. Culturally transmitted fears, distaste or love concerning certain groups of animals may result in the survival of certain species, while others may become extinct due to such reasons (CERÍACO 2012; DiCKMAN 2010). For certain groups of animals it is not only cultural and/or economic aspects which make conservation work more difficult, but aesthetic considerations as well. Such approaches are seldom in the focus of attention, even though emotional factors and aesthetic factors (such as morphological characteristics) may bear great significance in the eyes of a supportive public or of decision makers (BIRó et al. 2014; CERÍACO 2012).

Based on the ethnozoological research conducted in the four regions of the Carpathian Basin, the perception of Hungarian folk culture related to animals, in particular to vertebrate species is reviewed in this paper, and it is revealed that the cultural or economic judgement of which species or groups of species may have an impact on conservation efforts and which of them contradict the ecological significance of the species arising from their roles in the ecosystem.

\section{MATERIALS AND METHODS}

The research was made in four small regions of the Carpathian Basin (Gemer / Gömör - Slovakia, Sălaj / Szilágyság - Romania, Ghimeș / Gyimes - Romania and Baranja / Drávaszög - Croatia).

In three of the regions studied (Gemer / Gömör, Sălaj / Szilágyság, Baranja / Drávaszög) the typical climate is moderately continental, with an average annual amount of precipitation ranging up to $600-700 \mathrm{~mm}$, and an average annual temperature of $8-10{ }^{\circ} \mathrm{C}$ (BARTOLY - Bozó 2003). Potential vegetation is the climax community of deciduous oakwood forest with a mosaic pattern of wetland habitats (Quercetum petraea-cerris, Waldsteinio-Carpinetum). In Ghimeș (Gyimes), at an altitude of 8001300 metres above sea level, a boreal-montane climate is the predominant climate type with an average annual temperature of $4-6{ }^{\circ} \mathrm{C}$, and an annual amount of $800-1000$ mm precipitation in average (ILYÉs 2007; PÁLFALVI 1995). Potential vegetation consists mainly of woody plants (fir woods - Hieracio rotundati-Piceetum, to a lesser extents beech-woods - Symphyto cordati-Fagetum). The once continuous forest cover is now replaced by large areas of cleared, seminatural grasslands - mountain hay meadows and pastures: Trisetetum flavescentis, Arrhenatheretum elatioris, Festuco rubraeAgrostetum capillaris (BABAI et al. 2014). 
Extensive (traditional) land use is still a widely held practice in the regions investigated, maintaining a species rich anthropogenic cultural landscape. As a consequence, most respondents are full time workers in the agricultural sector. A total of 99 respondents were interviewed (16 in Gemer / Gömör, 20 in Sălaj / Szilágyság, 30 in Ghimeș / Gyimes, and 33 in Baranja / Drávaszög). Their average age was 72.5 years (71 in Gemer, 78 in Sălaj, 67 in Ghimeș and 74 in Baranja).

The primary goal of the research project was to draw up a basic assessment of ethnozoological knowledge. Traditional ecological knowledge was documented in relation to a total of 212 vertebrate species (BABAI 2011; ULICSNI 2012; ULICSNI et al. 2013; 2016). A number of unprompted statements were recorded in these interviews, dealing with the preferences of various species or groups of animals. Folk taxa, groups of species subject to positive or negative views from cultural or economic aspects were selected and the consequences of such attitudes on behalf of the respective communities were evaluated in terms of nature conservation. In the course of the mostly indoor interviews, free-listings (Which kind of birds, snakes etc. live here?) and, with the use of coloured photographs, structured interviews were accomplished, in a duration of approximately 120 hours. In average, the pictures of six similarly sized species of those found commonly in the surroundings of the settlement in question were put on an A4 format page, which were the starting points for respondents to talk about the species on the pictures and about those which occur in their surroundings. The method proved to be a practical tool to facilitate the perception of the scale, which caused difficulties in many cases during the preliminary assessments. When the characterisation given was not unequivocal enough, the exact determination of the species or species group in question could be appointed through the answers received to cross-questions concerning its less frequent properties. Interviews were transcribed word by word and all unsolicited data on the cultural perception of the species concerned were picked out of the texts. Such data were analysed hereinafter. Cultural and/or economic perception of each species was evaluated on a five stage scale $(-2-+2)$ in the four communities under investigation, and the average values of the figures received were illustrated on a graph, analysing specifically cultural and economic perception. Wherever it was possible, the reason for the bad reputation or for the respect was determined (cultural, economic, or both).

\section{RESULTS}

Approaches towards the various animal species are shaped by a number of cultural and/or economic aspects. In a review of the species included in the five conventional families of vertebrate animals it can be concluded that positive reputation of cultural origin would concern mainly birds. Negative approaches derived from cultural and/or economic factors can be observed in relation to amphibians and reptiles, plus a few mammals (Figures $1-2$ ).

In the regions under investigation the fish species are considered as neutral living beings in terms of culture and economy, practically no known fish species occurred in the statements and opinions with outstanding positive or negative cultural or economic aspects.

Amphibians and reptiles are inflicted by a typically bad reputation (apod reptiles, larger or strikingly glandulous-skinned frog and toad species). It is interesting, however, 


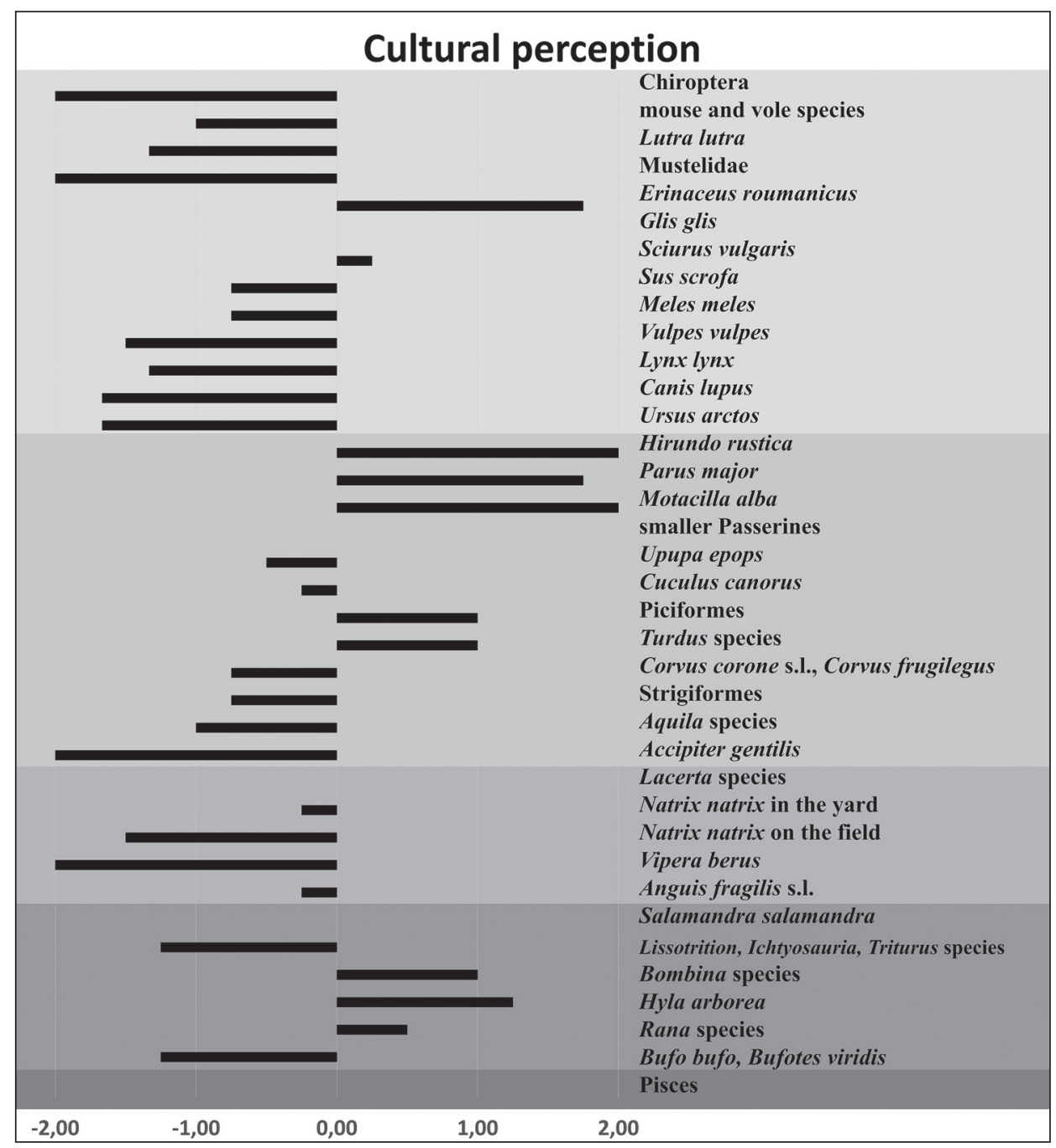

Figure 1. Estimated cultural perception of selected Vertebrates in the Carpathian Basin based on spontaneous statements of the informants during semi structured indoor interviews

how a few species (in Gyimes the common frog - Rana temporaria or, from the reptiles, the limbless elongated lizard, the Eastern slow worm - Anguis colchica) enjoy unusually high esteem, they are even featured in peasant Bible tales:

"we do have slow worm (Anguis colchica) here, it has a butt-edged tail. It was said, it has a butt-edged tail because when Noah had made the bark, it leaked and water poured in. And when the slow worm went there, it could plug it in ... It was the Devil who bore it with a drill, and the slow worm was able to put its tail in, so that no water could go in." (Gyimes, AB 0503 '10) 


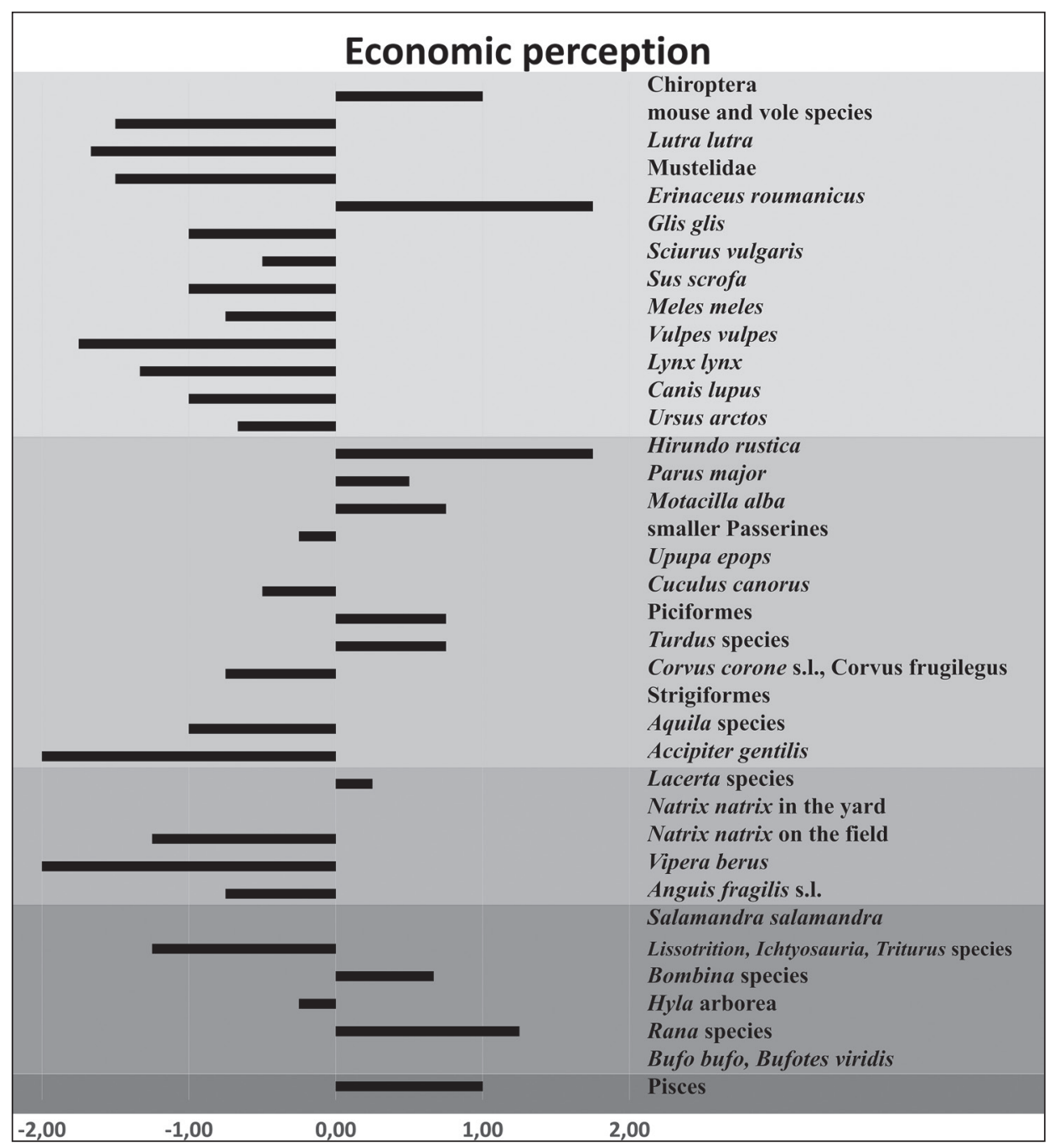

Figure 2. Putative economic perception by local people of selected Vertebrates in the Carpathian Basin based on spontaneous statements of the informants during semi structured indoor interviews

Hate towards toads (Bufo/Bufotes species) has specifically deep roots culturally. One of the reasons for this intolerant behaviour is that these species are seen as animals of rather poor aesthetic appearance: "maybe it would not harm me, yet I don't like to see it even on a picture" (Gömör, TK 2708 '12). A strongly cultural background confirms the negative perception related to toads in Gyimes region: "there are some people, who catch the scabby frog (common toad - Bufo bufo), it would make animals run dry (cows). Cows then will have such bad milk, thin milk, they kick, you can't milk them. This is true, this is reality. The warty frog is dangerous, maleficient kind" (TF 2202 '10). However, the impact of media can also be detected: "a harmful animal. And, on the other hand, it kills off the spiders, poisonous spiders from the pastures. It kills them off, this is why you 
must not destroy it” (Gyimes, GyJ 2602 '10). If this regulatory ecosystem service gets more and more to the foreground and the false beliefs related to drying cows are fading (professed by the elderly generations only, while personal experiences are restricted to a few people), the bad reputation of some toad species which are getting rare in several regions may be subject to change. These species, namely, became scarce indeed in two of the studied regions, in Gyimes ["the large, black scabby frog is very rare" (LG 2302 '10)] and in Gömör as observed and witnessed by locals ["it seldom occurs, by the way. Before, there were parts of the fields, or mainly in the woods, there were a lot. No big ones exist any more" (Gömör, KL 2808 '12)].

Snakes have a strikingly bad reputation even among reptiles. The reasons can be of religious and cultural origin, but also economic losses. The latter aspect emerges less frequently, but in such instances the dangerousness of vipers to children and farm animals is highlighted: "should it deal only with its own business, nobody would do any harm to it. However, it is hurt because it bites a number of cows and children as well. This is why a child must not be put on the ground. It is a beast, well, yet hardly anybody spares it" (Gyimes, AJ 2502 '16). As a consequence, almost all specimen of snakes detected are killed in the regions studied: "when hay making starts, they pull away, because folks set off, they persecute them. They have to leave because they go around in fear of their [...] lives." (Gyimes, PB 0503 '16) Additionally, according to some opinions, killing a snake might be beneficial for you: "if you hit a snake, you will be freed from seventy seven sins" (Gyimes, PB 0503 '16).

The destruction of snakes is irrelevant whether or not the snake species in question is dangerous, venomous or harmless. Members of traditional communities (for instance, Gyimes) behave the same way in other regions where no venomous snakes exist (a story from Hungary about the nonvenomous Aesculapian snake):

"[...] he did not drove on it, the man stopped, went there and grasped the big snake by the tail from behind, took it away and put it down. He said, you must not hit them. He told János so [the guest worker from Gyimes]. [But] János was afraid of them badly, hit them whenever he caught sight of one. [...] He killed them instantly and cleared them out, whenever the boss not near. However, when the boss was present, he always warned him not to hit them, they cause no harm to man. [...] It must be true for if not, they would be chased." (Gyimes, TS 0103 '16)

In the Gyimes region dead snakes are hanged from trees, fences and rocks, they are seldom left on the ground (Figures 3-5), because it is held that even the bones of an adder (Vipera berus) was poisonous, and it is not good for the grazing livestock or man to step on the bones of a snake: "he threw (the body of the snake) into water. Sad, to fling in, you never can tell, where it goes, how it goes, the cattle or anything, treads on the bones, it will sting it, it would lose its legs" (Gyimes, TA 2602 '16).

In all the four regions under investigation, a widely held belief says that a killed snake perishes irretrievably only after the Sun has set: "you have to break it, smash at its head. Why, it will be killed. It is said, before the Sun has gone down, it will still survive ... however you crash it, as long as the Sun is up, it will survive" (Gyimes, JGy 0203 '16).

Snakes found in open nature are smashed to death without exception, provided there are the appropriate tools and ways available to do so, although many are aware that adders and grass snakes (Natrix natrix) are quite useful by killing farm pests like small rodents 


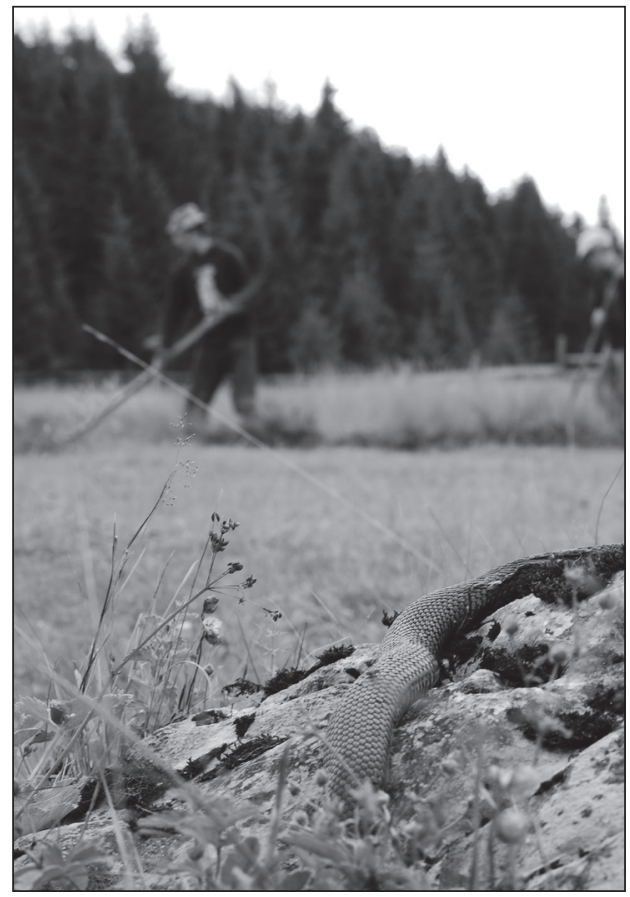

Figure 3. A viper killed during hay cutting, put on a rock. Háromkút, Bárány-hegy, 2009. (Photo by Ábel Molnár)

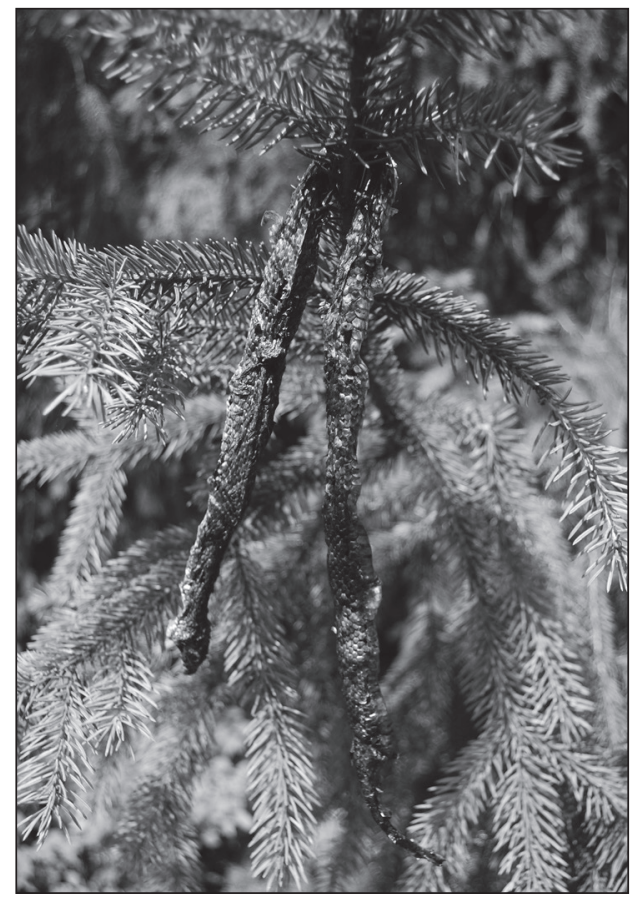

Figure 4. The body of a viper killed earlier on and hanged from the branch of a fir tree. Gyimesközéplok, Hidegségpataka, 2008. (Photo by Ábel Molnár)

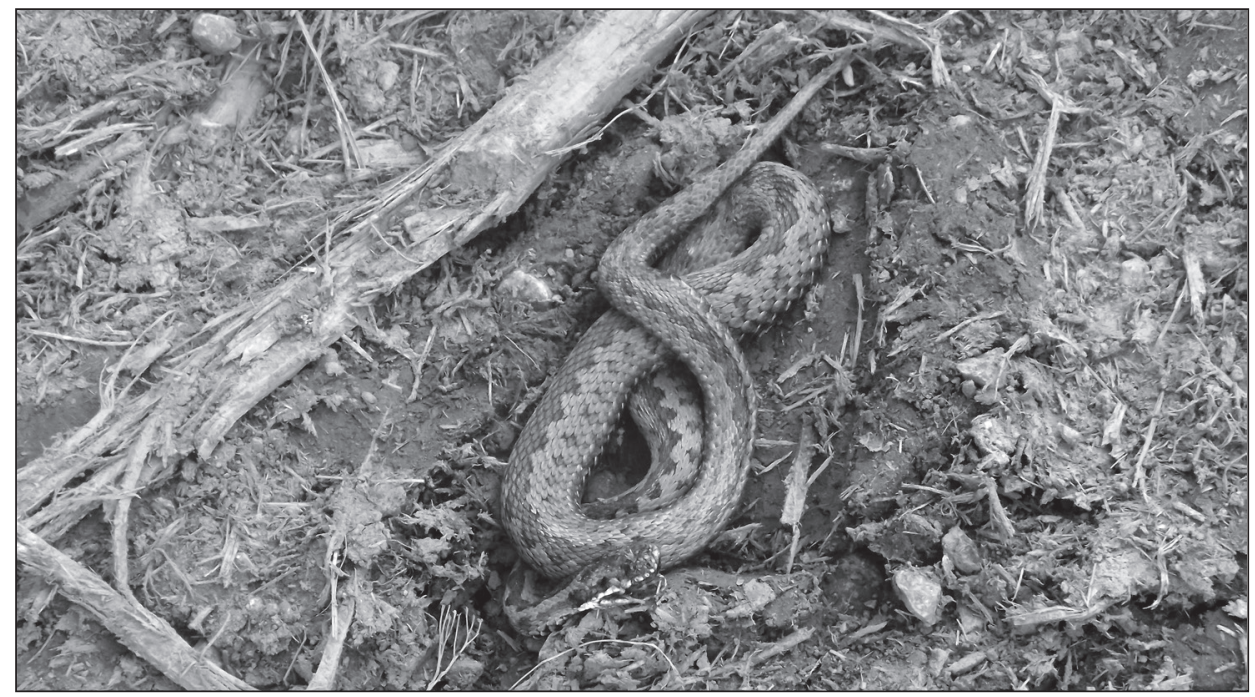

Figure 5. A viper smashed to death and left on the road. Gyimesközéplok, Hidegségpataka, 2015. (Photo by Dániel Babai) 


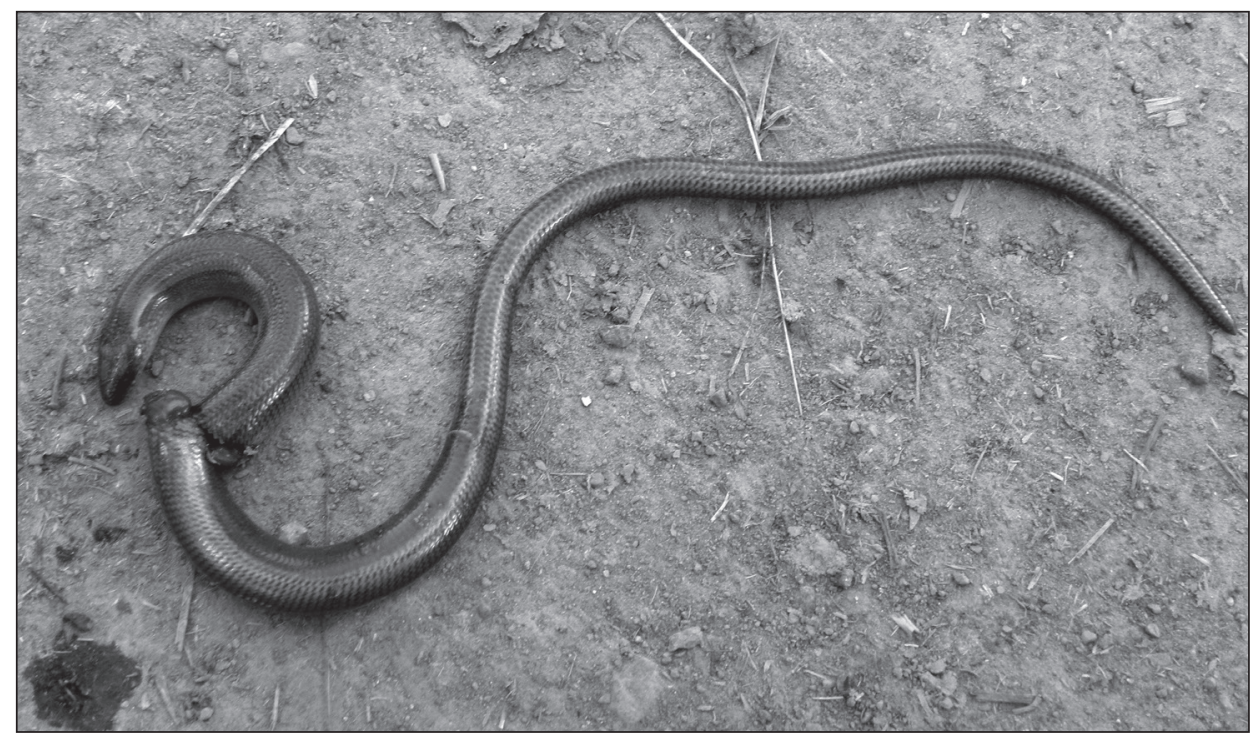

Figure 6. A freshly killed slow worm. Kárpátalja, 2013. (Photo by Viktor Ulicsni)

(mice and field voles). However, water snakes found around the house or in the stable wall are injured only on the rarest occasions. This practice, however, is not explained by their usefulness, rather by the superstitions associated with the mysterious house snakes:

\footnotetext{
“they say you shouldn't be afraid of that, it will do no harm. Lucky is the house where snakes live. They say it is like a watch-dog. And you don't be afraid of the other snake, [...] it will not hurt the children, if this one is present." (Drávaszög, SzI 2207 '12) / "A young man saw a white snake at the corner of the house, he stroke it dead. Why, in two weeks time [...] he was kicked by horse on the head that he died instantly. You must not harm such snakes." (Szilágyság, FA $\left.1206^{\prime} 10\right)$
}

Birds include species with positive and negative esteem alike. Some of them are thought to be harmful or others which really cause damages (e.g. hooded crow - Corvus cornix), but others are positively liked or even widely liked (for instance, the common white stork - Ciconia ciconia, barn-swallow - Hirundo rustica). Of the birds, mainly birds of prey have bad reputation, in particular the northern goshawk (Accipiter gentilis): "goshawks have always been shot, because it can catch doves and pigeons, damn it" (Drávaszög, LL 1707 '12). From time to time songbirds may also cause harm, such as the great tit (Parus major) which often pilfers cheese ["It punches the cheeses, that's what it does" (Gyimes, GyJ 2602 '10).] or a member of the thrush family (Turdidae), the fieldfare (Turdus pilaris) may also be unpopular for tapping fruits: "it likes fruit trees greatly, they nest there and eat the fruits so that you can't prevent them from eating. When the fruit is ripe, they eat it" (Gyimes, TS 2702 '10). It is interesting, how bad a reputation of the not too abundant white-throated dipper (Cinclus cinclus) has as a plunderer of fish: "it makes a lot of harm to small fish. It picks out fish eggs from the water, and the small fishes as well” (Gyimes, TS 2702 '10). 
Popular birds mostly include smaller songbirds (Passeriformes), which deserve such reputation by their singing: "it sings so nice, meaning spring is coming" (Gyimes, CsI 2702 '16). The cuckoo (Cuculus canorus) is in the focus in many places because of its special lifestyle: "I went out and heard the cuckoo singing, as it called up here yonder and it felt so nice" (Gyimes, PV 0203 '10); "Oh dear, how is it... When it sings, we are also pleased with the cuckoo" (Gyimes, 0103 '16).

As to mammals, you have to underline the case of large predators, which cause significant economic losses at some places but are basically held in low esteem everywhere (brown bear - Ursus arctos, grey wolf - Canis lupus, lynx - Lynx lynx). Large sized predators proliferating due to conservation efforts are typically a problem primarily in Gyimes, but they occur in Gömör as well, while in Szilágyság their memories are still living. Economic losses and the fear related to such species confirm negative judgements, in particular due to the strongly reproducing populations of bears and wolves. At the same time a kind of respect and curiosity can also be observed with respect to large predators, people are quite knowledgeable about the lifestyles of these species, their activities are followed with great interests, their traces are tracked in the land: "this ant-hunting bear $[\ldots]$ walks around rather during the night. I keep on listening, when I came away in the evening, there were no bear prints, and when I went there again in the morning to cut the hay, a big hole was dug and such an ant-hill in which he plundered in the night” (Kászon, SzJ 3007 '14).

Mainly smaller carnivore mammals like Mustelids are inflicted by unfavourable prejudices of cultural origin. This can most frequently be observed in relation to their name sake, the least weasel (Mustela nivalis): "the old people before used to say, the weasel bites on the udder of the cow. And it will swell up and will become painful and you have to get a treatment for it [...] its udder is spoilt" (Szilágyság NK 1907 '10); "It can be healed with the hide [of the weasel]" (Gyimes, TS 0103 '16). The fact that the least weasel is able to cause serious damages not only to cows but poultry stock - and in a wasteful manner, too, - does not improve its situation either: "it only sucks its blood, it will not eat the meat of the poultry" (Szilágyság, LL 1406 '10).

In many regions the representatives of the dormice are deemed to be a great pest which is specifically problematic (in particular the edible dormouse - Glis glis): "how it tortured me in the summer shelter. It chewed on the cheese. Somehow it came in. Well, it ate them all, chewed around it. [...] It ate enough there, whatever it could get hold of"' (Gyimes, TT 0103 '16).

The basically negative perception of bats (Chiroptera) is typical in all places, with interesting beliefs associated with them such as sticking to the hair ["we worried all the time that the bat would stick into our hairs [...] there was a doctor, he then wanted to go up on the attic of the church, but he was attacked" (Szilágyság, BE 1406 '10).] or transformation of old mice and shrews into bats ["my dad said to me that the bat will come from the old, old mice. Mice are getting transformed into bats through many-many years" (Gyimes, NI 0503 '16)]. The unfavourable attitude related to bats is magnified in a great extent due to their poor aesthetic appearance and mysterious night life: "I am afraid of it, it looks so ugly. It has ears like a mouse, I do not like mice either, they are not my friend” (Gyimes, FD 0203 '16). 


\section{DISCUSSION OF THE RESULTS}

Beliefs and emotions of people on their environment and the surrounding wildlife determine their behaviour towards them a great extent (PoOley - O'ConNOR 2000). False beliefs and negative perceptions originating from folklore influence people's approach to certain animal species clearly (CERÍACO 2012). Such fears may be irrational, cultural issues (BJERKE et al. 2001; KELLERT 1996) others may be specific phobias (BJERKE et al. 2001), or emotional reactions (KNIGHT 2008). The cause of the negative opinion may be assumed or true damage to husbandry (Treves et al. 2006). Therefore, the ethnozoological information gathered from local perceptions primarily to the negative and/or their economic background supports the efficacy of conservation measures related to species in need of protection due to human activities with important data (van MAANEN et al. 2001).

In the regions studied by the authors, practically no beliefs and assumptions or experiences related to damage causing behaviour exist with respect to fishes which would push the opinion on these species to an unfavourable direction. Their use as food reinforces their positive appreciation. In regions (such as along the river Tisza), where fishing and fishes are given a more important role in livelihood and nutrition, more definite positive and negative views from the economic or even cultural aspects occur (Borsos 1997; Solymos 2005).

Amphibians and reptiles have to endure an almost general aversion, in spite of the fact that they do not cause any substantial economic damages (though the people of Gyimes use such pretexts with respect to the adder - Vipera berus), what is more, several species are explicitly useful due to their ecological roles (PANDEY et al. 2016), as a source of food (FERRAND et al. 2001), or for medication (ALVES et al. 2008) eventually as other raw materials (Pough et al. 1998). The very low esteem of toad and snake species originating from cultural and partly economic reasons is indicated clearly by the statements on specific species turning up spontaneously during interviews in the Carpathian Basin as well.

The distaste for toads can be highlighted among amphibian species. The negative perception of the toad is triggered by the false beliefs related to the cows going dry or curses inflicted by witchcraft. Direct experiences related to such beliefs are held only by the elderly these days. Younger generations know about them only by indirect awareness obtained through story-telling: "are there any still around? / You can't hear about them nowadays. I hear, before, there were these old witches, I don't know, that $[\ldots]$ they kept toads" (Drávaszög, LJ 2307 '12). Thus, fading of the belief and the mitigation of the negative judgement can be expected (cf. Keszeg 2002). These beliefs had caused ruthless destruction of toads for instance in the Gyimes region, up to complete extinction just as well. In the meantime, more and more people have recognised the usefulness of these species (such as their feeding in insect pests). The impact of media (educational television channels, documentaries on nature) and environmental education efforts (cf. BURGHARDT et al. 2009) have been instrumental in changing perceptions. Negative attitudes and emotional reactions towards toads are driven not only by fears and beliefs but aesthetic reasons as well (KNIGHT 2008).

Reptiles are surrounded usually by greater hate than amphibians (CERÍACO 2012). This attitude can mainly be seen in the Carpathian Basin in the extremely negative perception 
of snakes. It is particularly typical with respect to snakes that their negative judgement is determined mainly by their dangerousness to human and potential risks rather than the role they play in the ecological system (pest control) (CERÍACo 2012; PANDEY et al. 2016). This negative approach is particularly complex and developed in parallel with human evolution (ISBELL 2006), irrespective whether it goes about venomous or nonvenomous snakes (PANDEY et al. 2016). Earlier on, reckless devastation mostly inflicted snakes detected in the outskirts of settlements, in the fields of the villages (ERDÉsz 1984), and spared those living near the house, because killing a snake close to your home meant bad luck and even a mistake which may cause death to the owner or a close relative. In certain locations, the belief held in the first place is that man is unable to kill snakes living in the house (SALÁNKI-FAZEKAS 2011). Today this belief has weakened and in Gyimes, for instance, vipers appearing beside the house are hit to death just as much as the specimens found in the hay meadows.

In Gyimes, the adder (besides large predators) is public enemy number one, which is killed systematically whenever encountered. Whenever a snake is killed, people think in Gyimes the animal will not perish until sunset and will continuously moving on up to that time. An explanation might be that it is always the head of the reptile which is smashed, thus the spinal chord is left intact and therefore the body would wriggle for a long time after the blow (Figure 3). Vipers are surrounded by hate and fear, because it would threaten the physical integrity of children and farm animals (cf. Australia: WHITAKER SHINE 2000; Nepal: PANDEY et al. 2016). It can be said in general that in the case of snakes the maximum potential damage they might cause has a greater weight than the real danger or damage when the actual frequency of the incidents is taken into account.

Deliberate killing of snakes, mainly venomous ones was typical throughout Europe during the $19^{\text {th }}$ and $20^{\text {th }}$ century, and still representing one of the biggest threat to the survival of the species up to date (Brito et al. 2001; Cox - Temple 2009). As a consequence, several species and populations died out in this period (for instance, the extinction of the Hungarian meadow viper in Austria, its repression in Romania - LANGTON - BURTON 1997; in Portugal - BRITo et al. 2001). The adder population in Gyimes, however, can be judged as stable, in spite of systematic persecution. Although there are no exact figures available on the existing population, local farmers continuously monitor the changes in the number of individuals setting up the population based on the number of individuals killed, and they do not feel any significant reduction. The substantial killing may be off-set by the non-targeted habitat protection fostered by traditional land use practices (Brooks et al. 2008).

Protection of amphibians and reptiles is definitely influenced by the surviving beliefs up to date, the resulting bad reputation and the poor accuracy of folk taxonomy, which is characteristic mostly for snakes (CERÍACO 2012). Locals sometimes are unfamiliar with the snake species present in the region they live in and they kill off all and any individuals encountered for the potential sensation of danger which can be derived from evolutionary (SAGAN 1977) and aesthetic (KNIGHT 2008) reasons as well (PANDEY et al. 2016). Such an approach is a disadvantage for the grass snake (Natrix natrix), which appeared only recently in Gyimes and is otherwise harmless. This must be taken into account when conservation efforts are planned (CERÍACO 2012; PANDEY et al. 2016).

For the perception of bird species, the economic damages caused by for instance eagles or great tits are evaluated more realistically compared to other baleful taxonomic 
groups and the basically positive cultural approach are of great significance in terms of the judgement of the species. Positive images are formed about several bird species as a consequence of their assumed capacity of weather forecasting and predictions in relation to a number of other topics (GránICZ 2015). Cultural ecosystem services such as the role of bird songs in recreational power are seldom mentioned by local farmers, yet most of such statements relate to bird species.

The views on mammal species are equally influenced by perceived and genuine economic aspects. The least favoured group is that of the bats, as this can be observed in many parts of the world (for instance in Brazil: FLECK et al. 2002; RAYMUNDO - CABALLES 2016; REGO et al. 2015). Bats are able to adapt to urbanised human environments, they survive in chimneys or buildings, therefore they are present and sometimes even thrive in settlements (REGO et al. 2015). The prejudices they are victims to are caused by bad reputation nourished by beliefs, in addition to the unfavourable aesthetic appearance (ProKoP - TUNNICLIFFE 2008). In several cultures in East-Asia encounter with a bat is a good sign (MULLEN 2005), but in most cultures worldwide (in particular in Western civilisation) these species are considered to be carriers of diseases and death (FREMBGEN 2006). In Brazil, the hate of bats can be derived from the blood sucking ones - most people judge the whole species group based on a few species only (REGO et al. 2015).

The underlying cause for the significant regional differences between the opinions on the various species of dormice is thought to be the difference in the land use practices present among the regions studied. Dormice are not eaten in Gyimes and in Szilágyság (ULICSNI et al. 2013), and in the former region its perception is basically unfavourable due to the damages made to cheese production (BABAI 2011). The presence of the sophisticated catching techniques in the regions can be associated with the hunting practices existing here earlier on and existing still elsewhere (CARPANETO - CRISTALDI 1998).

Certain mammal species become the target of human communities for fear and economic losses they cause. This can mainly be observed in the case of large predators representing a risk for both man and farm animals (such as the grey wolf, brown bear, snow leopard), which were deliberately killed in almost everywhere (e.g. BAGCHI - Mishra 2006; BJerke et al. 2000; Ceríaco 2012; Kleiven et al. 2004; Treves KARANTH 2003). Sometimes quite detailed and yet surprisingly accurate pictures are drawn up on such species (for instance lynx in the Gyimes and Macedonia, bear or wolf in the Szilágyság), with which there is a virtual absence of interactions (LESCUREUX LINNELL 2010). Populations of these species strengthened lately, thanks to conservation efforts. The phenomenon worries the population of those regions where they are present in greater numbers (for instance, in the Gyimes region).

\section{CONCLUSION}

Positive or negative relations to various vertebrate species may have a great impact on the conservation activities related to these species.

Our results also highlight which of the species would benefit from strengthened communication, mutual respect and acceptance of each other's position between nature conservation and local communities. It also point out the topics where awareness raising and improvement of environmental educational efforts for local communities are very 
important (Megaze et al. 2017). The use these means, such as information dissemination on the real role of the different animal species in the ecosystem - by highlighting the less apparent correlations - might be a lot more efficient than protection by the law (CERÍACO 2012). Folkloristic analysis may also be important in order to understand the kinds of beliefs surviving in contemporary communities, why they did survive and what consequences they will trigger in terms of the survival of the species concerned (CERÍACO 2012). In the meantime we should never forget that certain species are threatened by the vanishing traditional value order and the elimination of the taboo-like protection, causing a serious problem to conservation efforts (AIYADURAI 2016; COLDING - FOLKE 2001).

All in all, it can be stated that studies in ethnozoology may provide a significant amount of help when conservation strategies are developed by exploring local perceptions of species to be protected and the origins of such perceptions.

\section{ACKNOWLEDGEMENT}

We gratefully acknowledge all the people of Gömör/Gemer - Slovakia, Szilágyság/Sălaj - Romania, Gyimes/Ghimeș - Romania and Drávaszög/Baranja - Croatia who patiently and generously shared their knowledge with us. Thanks to István Tórizs and his family for their help with the field work.

Daniel Babai was supported by the János Bolyai Research Scholarship of the Hungarian Academy of Sciences. The work accomplished by Viktor Ulicsni was made possible through the institutional doctoral fellowship at the University of Szeged.

\section{REFERENCES CITED}

Aryadurai, Ambika

2016 'Tigers are Our Brothers.' Understanding Human-Nature Relations in the Mishmi Hills, Northeast India. Conservation and Society 14(4):305-316.

Alves, Rômulo Romeu da Nóbrega

2012 Relationships between Fauna and People and the Role of Ethnozoology in Animal Conservation. Ethnobiology and Conservation 1:1-69.

Alves, Rômulo Romeu da Nóbrega - Filho, Gentil Alves Pereira

2007 Commercialization and Use of Snakes in North and Northeastern Brazil. Implications for Conservation and Management. In HAwKsworth, David L. - Bull, Alan T. (eds) Vertebrate Conservation and Biodiversity, 143-159. Netherlands: Springer.

Alves, Rômulo Romeu da Nóbrega - Vieira, Washington Luiz da Silva - Santana, Gindomar Gomes

2008 Reptiles Used in Traditional Folk Medicine: Conservation Implications. Biodiversity and Conservation 17:2037-2049. 
Alves, Rômulo Romeu da Nóbrega - Silva, Vanessa N. - Trovẽo, Dilma M.B.M. Oliveira, José V. - Mourão, José S. - Dias, Thelma L.P. - Alves, Ângelo G.C. - Lucena, Reinaldo F.P. - Barboza, Raynner R.D. - Montenegro, Paulo F.G.P. VIEIRA, Washington L.S. - Souto, Wedson M.S.

2014 Students' Attitudes toward and Knowledge about Snakes in the Semiarid Region of Northeastern Brazil. Journal of Ethnobiology and Ethnomedicine $10: 30$.

BABAI, DÁNIEL

2011 Hagyományos ökológiai tudás az etnozoológia tükrében. A gerinces állatok népi ismerete Hidegségben [Traditional Ecological Knowledge in the Light of Ethnozoology. Folk Knowledge of Vertebrate Animals in Hidegség]. MA thesis, University of Pécs, Department of Ethnology and Cultural Anthropology, 69.

BABAi, Dániel - Molnár, Ábel - Molnár, Zsolt

2014 „Ahogy gondozza, úgy veszi hasznát”. Hagyományos ökológiai tudás és gazdálkodás a Gyimesben [Traditional Ecological Knowledge and Land Use in Gyimes (Eastern Carpathians)]. Budapest - Vácrátót: MTA Bölcsészettudományi Kutatóközpont Néprajztudományi Intézet - MTA Ökológiai Kutatóközpont Ökológiai és Botanikai Intézet.

BABAI, Dániel - Avar, Ákos - Ulicsni, Viktor

2016 "Veszélyes a varas béka, rossz fajzat" - avagy mit kutat az etnozoológus? ["The Toad is Dangerous, a Bad Lot" - in Other Words: What an Ethnozoologist Studies?] Kovász 20:3-29.

BAGCHI, Sumanta - Mishra, C.

2006 Living with Large Carnivores. Predation on Livestock by the Snow Leopard (Uncia uncia). Journal of Zoology 268:217-224.

BARTHOLY, Judit - Bozó, László

2003 Magyarország éghajlati atlasza [Climate Atlas of Hungary]. Budapest: Magyar Meteoróligiai Szolgálat.

BERKES, Fikret

2012 Sacred Ecology. Third Edition. New York, USA: Routledge.

BIRó, Éva - BABAI, Dániel - BóDIs, Judit - MolnÁr, Zsolt

2014 Lack of Knowledge or Loss of Knowledge? Traditional Ecological Knowledge of Population Dynamics of Threatened Plant Species in East-Central Europe. Journal for Nature Conservation 22:318-325.

BJERKe, Tore - VitTERsø, Joar - KALTEnBORn, Bjørn P.

2000 Locus of Control and Attitudes towards Large Carnivores. Psychological Reports 86:37-46.

BJerke, Tore - Kaltenborn, Bjørn P. - Thrane, Christer

2001 Sociodemographic Correlates of Fear-related Attitudes toward the Wolf (Canis lupus lupus). A Survey in South-Eastern Norway. Fauna Norvegica 21:25-33.

Borsos, Balázs

1997 Három folyó között. A bodrogközi gazdálkodás alkalmazkodása a természeti viszonyokhoz a folyószabályozási munkák elött és után (1840-1910) [Among the Three Rivers. Adaptation of Farming Practices to the Natural Conditions at the Time of River Draining Works (1840-1910)] Budapest: Akadémiai Kiadó. 
Brito, José C. - Rebelo, António - Crespo, Eduardo G.

2001 Viper Killings for Superstitious Reasons in Portugal. Boletín de la Asociación Herpetológica Española 12:101-104.

Brooks, Sharon E. - ReYNolds, John D. - Allison, Edward H.

2008 Sustained by Snakes? Seasonal Livelihood Strategies and Resource Conservation by Tonle Sap Fishers in Cambodia. Human Ecology 36:835.

Burghardt, Gordon - Murphy, James B. - Chiszar, David - Hutchins, Michael 2009 Combating Ophiophobia. Origins, Treatment, Education and Conservation Tools. In Mulin, Stephen J. - Seigel, Richard A. (eds) Snakes. Ecology and Conservation, 262-280. Cornell University Press.

Carpaneto, Giuseppe - Cristaldi, Mauro

1995 Dormice and Man. A Review of Past and Present Relations. Hystrix, the Italian Journal of Mammalogy 6(1-2):303-330.

CERÍACO, Luis M.P.

2012 Human Attitudes towards Herpetofauna. The Influence of Folklore and Negative Values on the Conservation of Amphibians and Reptiles in Portugal. Journal of Ethnobiology and Ethnomedicine 8:8.

Colding, Johan - Folke, Carl

2001 Social Taboos. "Invisible" Systems of Local Resource Management and Biological Conservation. Ecological Application 11:584-600.

Cox, N.A. - Temple, H.J.

2009 European Red List of Reptiles Luxembourg. Office for Official Publications of the European Communities.

Dickman, Amy J.

2010 Complexities of Conflict. The Importance of Considering Social Actors for Effectively Resolving Human-Wildlife Conflict. Animal Conservation $13: 458-466$.

ERDÉSZ, Sándor

1972 Fehér kígyó a magyar néphagyományban [White Snake in Hungarian Folk Traditions]. A nyíregyházi Jósa András Múzeum Évkönyve 12-14:73-91.

1984 Kígyókultusz a magyar néphagyományban [Snake Cult in Hungarian Folk Tradition]. Debrecen: Kossuth Lajos Tudományegyetem Néprajzi Tanszéke.

Ferrand, Nuno - Ferrand, Paulo - Gonçalves, Helena - Sequeira, Fernando TeIXeIra, José - Ferrand, Francisco

2001 Guia dos Anfibios e Répteis de Portugal Porto. Portugal: Guias Fapas/Câmara Municipal do Porto.

Fita, Dídac S. - Neto, Eraldo Costa M. - Schiavetti, Alexandre

2010 'Offensive' Snakes. Cultural Beliefs and Practices Related to Snakebites in a Brazilian Rural Settlement. Journal of Ethnobiology and Ethnomedicine 6:13.

Fleck, David Williams - Voss, Robert S. - Simmons, Nancy B.

2002 Underdifferentiated Taxa and Sublexical Categorization. An Example from Matses Classification of Bats. Journal of Ethnobiology 22:61-102.

FREMBGEN, Jürgen Wasim

2006 Embodying Evil and Bad Luck. Stray Notes on the Folklore of Bats in Southwest Asia. Asian Folklore Studies 65(2):241-247. 
GRÁNICZ, Laura

2015 Népi emlős- és madárismeret Alszegen. [Folk Knowledge of Mammals and Birds in Alszeg]. In Molnár, Krisztina - Molnár, Zsolt (eds) Élet és rend a határban. Etnoökológiai Kutatótábor Kalotaszegen [Life and Order in the Fields. Research Camp for Ethnoecology in Kalotaszeg], Sztánai Füzetek 19:184-189. Kolozsvár (Cluj) - Sztána (Stana): Müvelődés Egyesület Szentimrei Alapítvány.

GuB, Jenő

1996 Erdö-mezö állatai a Sóvidéken [Animals of Forests and Meadows in the Salt Country]. Firtos Müvelődési Egylet, Korond.

Herman, Ottó

1901 A madarak hasznáról és káráról (Vol. 6) [Of the Use and Harm of Birds (Vol.

6)]. Budapest: Franklin-Társulat Nyomdája.

Huntington, Henry P.

2000 Using Traditional Ecological Knowledge in Science. Methods and Applications. Ecological Applications 10(5):1270-1274.

ILYÉs, Zoltán

2007 A tájhasználat változásai és a történeti kultúrtáj 18-20. századi fejlödése Gyimesben. [Changes in Land Use and the Development of the Historical Cultural Landscape in the $18-20^{\text {th }}$ Centuries in Gyimes]. Eger: Eszterházy Károly Főiskola.

ISBELL, Lynne A.

2006 Snakes as Agents of Evolutionary Change in Primate Brains. Journal of Human Evolution 51(1):1-35.

Joshi, Tankesh - Joshi, Muktesh

2010 Ethno-Ophiology - A Traditional Knowledge among Tribes and Non-Tribes of Bastar, Chhattisgarh. Indian Journal of Traditional Knowledge 9:137-139.

KeLLERT, Stephen R.

1996 The Value of Life. Biological Diversity and Human Society. Washington DC, USA: Island Press.

KeSZEG, Vilmos

2002 Homo narrans. Emberek, történetek és kontextusok [Homo Narrans. Men, Stories and Contexts]. Kolozsvár: Komp-Press.

Kleiven, Jo - Bjerke, Tore - Kaltenborn, Bjørn P.

2004 Factors Influencing the Social Acceptability of Large Carnivore Behaviors. Biodiversity and Conservation 13:1647-1658.

KNIGHT, Andrew J.

2008 "Bats, Snakes and Spiders, Oh My!" How Aesthetic and Negativistic Attitudes, and Other Concepts Predict Support for Species Protection. Journal of Environmental Psychology 28:94-103.

KovÁcs, Antal

1987 Járok-kelek gyöngyharmaton... Növény- és állatnevek a Felsö-Szigetköz tájnyelvében [I Come and Go on Morning Dew... Plant and Animal Names in the Upper Szigetköz Dialect]. Mosonmagyaróvári Helytörténeti Füzetek 6. 
Lamarque, F. - Anderson, J. - Fergusson, R. - Lagrange, M. - Osei-Owusu, Y. BAKKER, L.

2009 Human-Wildlife Conflict in Africa. Causes, Consequences and Management Strategies (No. 157). Roma (Italy): Food and Agriculture Organization of the United Nations (FAO).

LANGTON, Tom - BuRTON, John A.

1997 Amphibians and Reptiles - Conservation Management of Species and Habitats. Strasbourg: Council of Europe Publishing.

LESCUREUX, Nicolas - LinNell, John D.

2010 Knowledge and Perceptions of Macedonian Hunters and Herders. The Influence of Species Specific Ecology of Bears, Wolves, and Lynx. Human Ecology 38:389-399.

van MAanen, Erwin - Goradze, Irakli - Gavashelishvili, Alexander - Goradze, Rezo 2001 Trapping and Hunting of Migratory Raptors in Western Georgia. Bird Conservation International 11:77-92.

Mascia, B. Michael - Brosius, J. Peter - Dobson, Tracy A. - Forbes, Bruce C. Horowitz, Leah - McKean, Margaret A. - Turner, Nancy J.

2003 Conservation and the Social Sciences. Conservation Biology 17(3):649-650.

Megaze, Aberham - Balakrishnan, Mundanthra - Belay, Gurja

2017 The Attitudes and Practices of Local People towards Wildlife in Chebera Churchura National Park, Ethiopia. International Journal of Biodiversity and Conservation 9:45-55.

Menzies, Charles R. - ButLer, Caroline

2006 Introduction. Understanding Ecological Knowledge. In Menzies, C.R. (ed) Traditional Ecological Knowledge and Resource Management, 1-16. Lincoln and London: University of Nebraska Press.

MidDleton, Beth A.

2012 Rediscovering Traditional Vegetation Management in Preserves. Trading Experiences between Cultures and Continents. Biological Conservation 158:271-279.

MulLen, Nicole

2005 Chinese Folk Art, Festivals, and Symbolism in Everyday Life. Berkeley: Phoebe A. Hearst Museum of Anthropology.

Moura, Mário Riberio de - Costa, Henrique Calderia - SÃo-Pedro, Vinicius de Avelar - Fernandes, Vitor Dias - Feio, Renato Neves

2010 The Relationship between People and Snakes in Eastern Minas Gerais, SouthEastern Brazil. Biota Neotropica 10:133-141.

NADASDY, Paul

2007 The Gift in the Animal. The Ontology of Hunting and Human-Animal Sociality. American Ethnologist 34:25-43.

PÁlfaLVI, Pál

1995 A Gyimesi-hágó (1164 m) környékének florisztikai vázlata [Floristic Outlines of the Surroundings in the Gyimes Pass (1164 m)]. Múzeumi Füzetek (Az Erdélyi Múzeum Egyesület Természettudományi és Matematikai Szakosztályának Közleményei) 4:107-114. 
Pandey, Deb Prasad - Pandey, Gita Subedi - Devkota, Kamal - Goode, Matt

2016 Public Perceptions of Snakes and Snakebite Management. Implications for Conservation and Human Health in Southern Nepal. Journal of Ethnobiology and Ethnomedicine 12:22.

Pilgrim, Sarah E. - Cullen, Leanne C. - Smith, David J. - Pretty, Jules

2008 Ecological Knowledge is Lost in Wealthier Communities and Countries. Environmental Science and Technology 42(4):1004-1009.

Pinheiro, Luan Tavares - Rodrigues, João Fabricio Mota - Borges-NojosA, Diva Maria

2016 Formal Education, Previous Interaction and Perception Influence the Attitudes of People toward the Conservation of Snakes in a Large Urban Center of Northeastern Brazil. Journal of Ethnobiology and Ethnomedicine 12:25.

Pooley, Julie Ann - O’Connor, Moira

2000 Environmental Education and Attitudes: Emotions and Beliefs Are What is Needed. Environment and Behavior 32(5):711-723.

Pough, F.H. - Andrews, R.M. - Cadle, J.E. - Crump, M.L. - SavitzKy A.H. - Wells, K.D.

1998 Herpetology Upper Saddle River, NJ, USA: Prentice-Hall.

Prokop, Pavol - Tunnicliffe, Suel Dale

2008 "Disgusting" Animals: Primary School Children's Attitudes and Myths of Bats and Spiders. EURASIA Journal of Mathematics, Science and Technology Education 4(2):87-97.

Raymundo, M.L. - Caballes, C.F.

2016 An Insight into Bat Hunter Behavior and Perception with Implications for the Conservation of the Critically Endangered Philippine Bare-Backed Fruit Bat. Journal of Ethnobiology 36(2):382-394.

Rego, Karlla Morgana da Costa - ZePpelini, Caio Graco - Alves, Rômulo Romeu da Nóbrega

2015 Assessing Human-Bat Interactions Around a Protected Area in Northeastern

RóHeIM, Géza

Brazil. Journal of Ethnobiology and Ethnomedicine 11:80.

1925 Magyar néphit és népszokások [Hungarian Popular Beliefs and Folk Traditions]. Budapest.

SAGAN, Carl

1977 Dragons of Eden. United Kingdom: Ballantine Books.

SALÁNKI-FAZEKAS, Éva

2011 Egy berettyószéplaki cigány asszony hiedelmei [Beliefs of a Gypsy Woman from Berettyószéplak.]. Erdélyi Múzeum 1:121-137.

SALICK, Jan

2003 Intellectual Imperatives in Ethnobiology. NSF Biocomplexity Workshop Report. St. Louis: Missouri Botanical Garden.

Solymos, Ede

2005 Dunai halászat. Hagyományos halászat a magyar Dunán [Fishing on the Danube. Traditional Fishing on the Hungarian Reach of the River Danube]. Budapest: Akadémiai Kiadó. 
TreVes, Adrian - Karanth, K. Ullas

2003 Human-Carnivore Conflict and Perspectives on Carnivore Management Worldwide. Conservation Biology 17(6):1491-1499.

Treves, Adrian - Wallace, Robert B. - Naughton-Treves, Lisa - Morales, Andrea 2006 Co-Managing Human-Wildlife Conflicts: a Review. Human Dimensions of Wildlife 11(6):383-396.

ULICSNI, Viktor

2012 Vadonélő emlősfajok etnobiológiája Szilágynagyfalun [Ethnobiology of Wild Mammal Species in Szilágynagyfalu]. BSc Thesis, Szegedi Tudományegyetem.

ULICSNI, Viktor - SvANBERG, Ingvar - MOLNÁR, Zsolt

2013 Folk Knowledge of Non-Domestic Mammals among Ethnic Hungarians in North-Western Romania. North-Western Journal of Zoology 9:383-398.

2016 Folk Knowledge of Invertebrates in Central Europe - Folk Taxonomy, Nomenclature, Medicinal and other Uses, Folklore, and Nature Conservation. Journal of Ethnobiology and Ethnomedicine 12:47.

WhITAKeR, Patrick B. - SHINe, Richard

2000 Sources of Mortality of Large Elapid Snakes in an Agricultural Landscape. Journal of Herpetology 34(1):121-128.

WOJNOWSKI, D.

2009 Scientific and Traditional Conceptions of Snakes in Kenya. Herpetologists as Teacher Mentors. Herpetological Review 40(2):158.

See biography of Dániel Babai at the end of guest editors' foreword: Ecological Anthropological Research in Hungary, at page 29.

Ákos Avar (PhD) is a lecturer at the Department of Mongolian and Inner Asian Studies at Eötvös Loránd University, Budapest. He has extensive field experience in Mongolia. He defended his PhD thesis titled "Nature and Animals in the Mongolian Traditional Thinking" in 2013. The dissertation was published in Hungarian as a book with the same title: A természet és az állatok a hagyományos mongol gondolkodásban, Budapest: Equinter, 2014. Besides his academic career he manages an animal farm specialized on the preservation and breeding of traditional domestic species of the racka sheep. Email-address: avar.akos@ gmail.com

Viktor Ulicsni is a PhD Student at the Department of Ecology, University of Szeged. He is an ethnozoologist and ecologist working in the Carpathian Basin and Moldova. E-mail address: ulicsni.viktor@t-online.hu 